\title{
MAXIMAL FAT OXIDATION DURING AEROBIC EXERCISE IN ADOLESCENTS WITH TYPE 1 DIABETES
}

\author{
OXIDAÇÃOMÁXIMA DE GORDURAS DURANTE O EXERCÍCIO AERÓBICO EM ADOLESCENTES COM \\ DIABETES TIPO 1
}

OXIDACIÓN MÁXIMA DE GRASAS DURANTEELL EJERCICIO AERÓBICO EN ADOLESCENTES CON DIABETES TIPO 1
Íncare Correa de Jesus ${ }^{1}$

(Physical Education Professional)

Luis Paulo Gomes Mascarenhas²,3 (Physical Education Professional) Valderi Abreu de Lima ${ }^{2,3}$

(Physical Education Professional)

Juliana Pereira Decimo ${ }^{3}$

(Physical Education Professional)

Suzana Nesi-França ${ }^{3}$

(Pediatric Endocrinologist)

Neiva Leite ${ }^{1}$

(Physical Education Professional and Pediatrician)

1. Universidade Federal do Paraná (UFPR), Department of Physical

Education, Quality of Life Center. Curitiba, PR, Brazil.

2. Universidade Estadual do Centro Oeste (UNICENTRO), Irati, PR, Brazil. 3. Universidade Federal do Paraná (UFPR), Department of Pediatrics Pediatric, Endocrinology Unit, Curitiba, PR, Brazil.

\section{Correspondence:}

Íncare Correa de Jesus Universidade Federal do Paraná Núcleo de Pesquisa de Qualidade de Vida. Rua Coração de Maria, 92 , Jardim Botânico, Curitiba, PR, Brazil. 82590-300. asp.incare@hotmail.com

\begin{abstract}
Objective: To compare maximal fat oxidation rates (FATMAX) and analyze their association with cardiorespiratory fitness in adolescents with type 1 diabetes mellitus (T1DM). Methods: Twenty-two male and female adolescents aged between 11 to 17 years, following clinical and anthropometric evaluations, were assigned to the diabetic group (DG; $n=10$ ) or control group (CG; $n=12$ ). Cardiorespiratory fitness was determined by maximal oxygen uptake $\left(\mathrm{VO}_{2 \max }\right)$ during a maximal aerobic test on a cycle ergometer using the Balke protocol. Maximal fat oxidation (FATMAX) was determined by the respiratory exchange ratio proposed in the Lusk table. Results: Adolescents in the DG had lower mean FATMAX $(p<0.01)$ and $\% \mathrm{VO}_{\text {2FATMAX }}(p=0.001)$ values when compared with those in the CG. FATMAX values were inversely correlated with serum glycosylated hemoglobin (HBA1c) levels $(r=-0.77)$ and directly correlated with BMI z-scores $(r=0.76)$, while $\% \mathrm{VO}_{2 \text { FATMAX }}$ results were correlated with age $(r=0.81)$, BMI z-scores $(r=0.65)$, and $V_{2}{ }_{2 \max }$ values $(r=0.81)$. On multiple linear regression, $\mathrm{HbA1}$ c values explained 54\% (adjusted $r^{2}=0.54, p=0.009$ ) and BMI $z$-scores explained $3.1 \%$ (adjusted $r^{2}=-0.031$, $\mathrm{p}=0.009$ ) of the variation in FATMAX in the DG. Adolescents with T1DM had similar cardiorespiratory fitness and lower FATMAX rates ( $35 \pm 11 \mathrm{VO} 2 \mathrm{max})$ when compared with controls $\left(60 \pm 12 \mathrm{VO}_{2 \max }\right)$. Conclusion: These results suggest lower fat oxidation rates and greater use of glucose as an energy substrate during exercise and worse control in T1DM. Therefore, results may contribute to appropriate exercise prescription in T1DM, after verifying exercise intensity to reduce hypoglycemia risk. Level of evidence III; Case-control study.
\end{abstract}

Keywords: Lipolysis; Diabetes mellitus, type 1; Exercise; Adolescents.

\section{RESUMO}

Objetivo: Comparar as taxas máximas de oxidação da gordura (FATMAX) e analisar a sua associação com a aptidão cardiorrespiratória em adolescentes com diabetes mellitus tipo 1 (DM1). Métodos: Vinte e dois adolescentes de ambos os sexos, de 11 a 17 anos, após avaliações clínicas e antropométricas, foram alocados no grupo diabético (GD; $n=10$ ) ou no grupo controle $(G C ; n=12)$. A aptidão cardiorrespiratória foi determinada pelo consumo máximo de oxigênio $\left(V_{2}{ }_{2 m a x}\right)$ durante um teste aeróbico máximo em um cicloergômetro utilizando o protocolo Balke. A oxidação máxima da gordura (FATMAX) foi determinada pela razão de troca ventilatória proposta na Tabela de Lusk. Resultados: Os adolescentes no GD apresentaram menores valores médios de FATMAX $(p<0,01)$ e\% VO ${ }_{2 F A T M A X}(p=0,001)$ quando comparados com aqueles no GC. Os valores de FATMAX correlacionaram-se inversamente com os niveis de hemoglobina glicosilada sérica (HbATC) ( $r=$ -0,77) e diretamente com o z-score IMC $(r=0,76)$, enquanto os resultados de \%VO ${ }_{2 F A T M A x}$ Correlacionaram-se diretamente com a idade $(r=0,81)$, $z$-score IMC $(r=0,65)$ eVO 2max $_{2}(r=0,81)$. Na regressão linear múltipla, os valores de HbA1c explicaram $54 \%\left(r^{2}\right.$ ajustado $\left.=0,54, p=0,009\right)$ e o $z$-score IMC explicou 3,1\% ( $r^{2}$ ajustado = =0,031, $\left.p=0,009\right)$ da variação no FATMAX no GD. Os adolescentes com DM1 apresentaram aptidão cardiorespiratória similar e taxas de FATMAX menores ( $35 \pm 11$ $\mathrm{VO}_{2 \max }$ quando comparados com os do grupo controle $\left(60 \pm 12 \mathrm{VO}_{2 \max }\right)$. Conclusão: Esses resultados sugerem taxas menores de oxidação da gordura e maior uso da glicose como substrato de energia durante o exercício e pior controle no DM1. Portanto, os resultados podem contribuir com a prescrição de exercício apropriada no DM1, após verificar a intensidade do exercício, a fim de diminuir o risco de hipoglicemia. Nível de evidência III; Estudo de caso-controle.

Descritores: Lipólise; Diabetes mellitus tipo 1; Exercício; Adolescentes.

\section{RESUMEN}

Objetivo: Comparar las tasas máximas de oxidación de la grasa (FATMAX) y analizar su asociación con la aptitud cardiorrespiratoria en adolescentes con diabetes mellitus tipo 1 (DM1). Métodos: Veintidós adolescentes de ambos sexos, de 11 a 17 años, después de evaluaciones clínicas y antropométricas, fueron asignados en el grupo diabético ( $G D, n=10)$ o en el grupo control (GC, $n=12)$. La aptitud cardiorrespiratoria fue determinada por el consumo máximo de oxígeno $\left(V_{2 \text { max }}\right)$ durante un test aeróbico máximo en un cicloergómetro utilizando el protocolo Balke. La oxidación máxima de la grasa (FATMAX) fue determinada por la razón de cambio ventilatorio propuesta en la Tabla de Lusk. Resultados: Los adolescentes en el GD presentaron menores valores promedio de $\operatorname{FATMAX}(p<0,01)$ y $\% V_{\text {EFATMAX }}(p=0,001)$ cuando comparados con aquellos en el GC. Los valores de FATMAX se correlacionaron inversamente con los niveles de hemoglobina glicosilada sérica (HbA1C) 
$(r=-0,77)$ y directamente con el $z$-score IMC $(r=0,76)$, mientras que los resultados de \% $\mathrm{VO}_{2 \text { FATMAX }}$ se correlacionaron directamente con la edad $(r=0,81), z$-score IMC $(r=0,65)$ y $V_{2 \text { max }}(r=0,81)$. En la regresión lineal múltiple, los valores de HbAlc explicaron 54\% ( $r^{2}$ ajustado =0,54, $\left.p=0,009\right)$ y el $z$-score IMC explicó 3,1\% ( $r^{2}$ ajustado =-0,031, $\left.p=0,009\right)$ de la variación en el FATMAX en el GD. Los adolescentes con DM1 presentaron aptitud cardiorrespiratoria similar y tasas de FATMAX menores $\left(35 \pm 11 \mathrm{VO}_{2 \max }\right.$ ) cuando comparados con los del grupo control $\left(60 \pm 12 \mathrm{VO}_{2 \max }\right.$ ). Conclusión: Esos resultados sugieren tasas menores de oxidación de la grasa y mayor uso de la glucosa como substrato de energía durante el ejercicio y peor control en la DM1. Por lo tanto, los resultados pueden contribuir con la prescripción de ejercicio apropiada en la DM1, después de verificar la intensidad del ejercicio, a fin de disminuir el riesgo de hipoglucemia. Nivel de evidencia III; Estudio de caso-control.

Descriptores: Lipólisis; Diabetes mellitus tipo 1; Ejercicio; Adolescentes.

\section{INTRODUCTION}

Type 1 diabetes mellitus (T1DM) is one of the most frequent chronic diseases in the pediatric population and its incidence has increased in the world. ${ }^{1}$ The prevalence of T1DM in Brazil varies based on regional studies between 7.6 and 12.0/100,000 persons-year. ${ }^{2}$ The occurrence of T1DM has been associated with an increased risk of cardiovascular diseases in adult life and therapy is complex and difficult, including adequate insulin administration, food control and regular physical activity. ${ }^{1,3}$ Regular practice of physical exercise develops an individual's fitness and overall health, reducing cardiovascular risk factors, improving lipid metabolism, and increasing insulin sensitivity, particularly at the skeletal muscle. ${ }^{4}$ Nonetheless, physical activity may upsurge the risk of episodes of hypoglycemia during and after exercise, a factor that limits the adherence of many patients with T1DM. ${ }^{4,5}$

The American Diabetes Association recommends all levels of physical exercise (including leisure activities) and recreational and competitive sports for young individuals with T1DM with proper blood glucose control and without chronic complications. ${ }^{6}$ However, young individuals with T1DM must be aware that physical exercise interferes with glucose homeostasis, and that metabolic responses may differ depending on type, duration, and intensity of the exercise and on serum concentration of glucose and insulin before the exercise. ${ }^{3,6}$ The benefits promoted by regular physical exercise outweigh the risk of hypoglycemia during a physical activity when the individual complies with instructions to reduce the dose of insulin, carbohydrate intake, maintain hydration, and evaluate the characteristics of the activity that will be performed. 4,5

Carbohydrate oxidation generally increases in proportion to the intensity of the exercise. However, fat oxidation increases initially from low- to moderate-intensity exercise but then decreases again during high-intensity exercise. ${ }^{3,7}$ Maximization of fat oxidation during exercise may bring health benefits, help control weight, and reduce the dependence of glucose as a source of energy. ${ }^{8}$

Despite these advantages, the treatment of the patient with DM1 and reduction of hypoglycemia risks depend on the appropriate adjustment of healthy eating, insulin therapy and the intensity of physical activity., The contribution of fat or carbohydrates as an energy source during exercise depends primarily on exercise intensity, but the disposal of glucose in individuals with type 1 diabetes mellitus (T1DM) may influence the choice of energetic substrate during exercise. ${ }^{7,9}$

There are limited studies evaluating the metabolism of fat during exercise in children and adolescents with T1DM. Considering that, we conducted this study to compare the rates of maximal fat oxidation (FATMAX) and cardiorespiratory fitness in adolescents with and without T1DM and to analyze the association of FATMAX values with anthropometric variables and cardiorespiratory fitness in the subgroup of patients with T1DM.

\section{MATERIAL AND METHODS}

This cross-sectional and observational study included a convenience sample of patients with T1DM recruited from an outpatient clinic of the Pediatric Endocrinology Unit at Hospital de Clínicas, and matched control individuals recruited from schools in the city of Curitiba (Paraná, Brazil). The overall cohort included 30 individuals of both sexes and aged between 11 and 17 years. Individuals with T1DM were allocated to a diabetic group, whereas those without diabetes were placed in a control group. The inclusion criteria of the study comprised a diagnosis of T1DM without other associated pathologies (for participants included in the diabetic group); absence of chronic diseases such as type 2 diabetes mellitus, hypothyroidism, other endocrine diseases, infections, and use of medications that promote changes in adiposity, metabolic parameters, or inflammatory markers. We used as an exclusion criterion the occurrence of obesity, using diagnostic criteria proposed by the World Health Organization.

The participants in both groups underwent a clinical evaluation that included a complete medical history and physical examination, anthropometric measurements, family history, and analysis of sexual maturation based on Tanner's staging. ${ }^{10}$ Eight obese adolescents were excluded from the study after a medical assessment. Of the remaining participants, 10 were allocated to the diabetic group and 12 to the control group, as shown in Figure 1.

None of the participants had cardiac, pulmonary, or osteoarticular conditions that could compromise the achievement of submaximal effort during exercise on a cycle ergometer. All volunteers practiced physical education regularly at school during the previous 6 months (120 min/ week). Blood levels of glycosylated hemoglobin ( $\mathrm{HbA1c}$ ) in adolescents with T1DM were analyzed by high-performance liquid chromatography (HPLC). All volunteers (and their parents or guardians) were informed about the study procedures and agreed with the participation of the

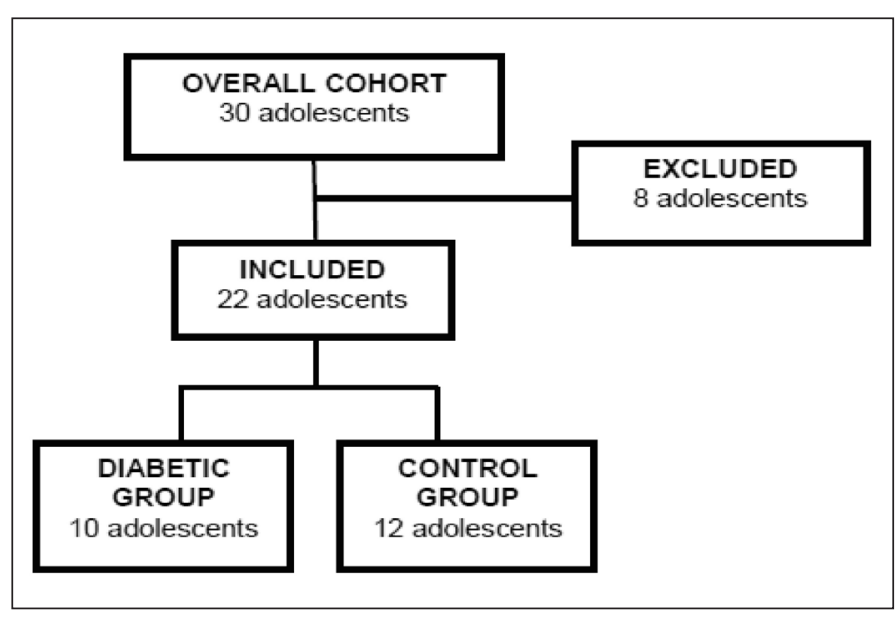

Figure 1. Flow diagram showing the cohort selection process. 
volunteers after signing a free and informed consent form (TCLE). The study was approved by the institution's Ethics Committee on Human Research under protocol number 44193214.7.0000.0096.

The body mass (in $\mathrm{kg}$ ) was measured on a platform scale accurate to $0.1 \mathrm{~kg}$ and with a maximum measurement of $150 \mathrm{~kg}$. The height of the participants was measured at the end of maximum inspiration with a stadiometer fixed to the wall, accurate to $0.1 \mathrm{~cm}$ and with a maximum measurement of $220 \mathrm{~cm}$. We calculated the participants'body mass index (BMI) and classified the results according to sex and age, as defined by the World Health Organization. ${ }^{11}$ We considered as eutrophic those participants with BMI z-scores for age $\geq-2$ but $<+1$, and as overweight those with results $\geq+1$ but $<+2$.

The $\mathrm{VO}_{2}$ max test was performed with a portable gas analyzer (K4b2 ${ }^{\circledR}$, Cosmed) on a cycle ergometer using the adapted Balke protocol. ${ }^{12}$ The protocol consists of starting the test with a load of 25 watts and speed of 50 rpm, followed by a 25-watt load increase every three minutes until achievement of maximal heart rate $(\mathrm{HR})$ or inability to maintain speed and load. The test is considered maximal when two of the following criteria are observed: a) exhaustion or inability to maintain the required speed; b) ventilatory exchange ratio $(R) \geq 1.09$; and $c)$ achievement of the anticipated maximal HR calculated with the formula 208 - $(0.7 x$ age), proposed by Tanaka et al. ${ }^{13}$ The highest $\mathrm{VO}_{2}$ obtained during the incremental test was established as the individual's $\mathrm{VO}_{2}$ max. To calculate the FATMAX values, we used the ventilatory exchange ratio (R) observed during the maximal aerobic exercise test, as proposed by Lusk. ${ }^{14}$

The data are presented as mean and standard deviation, and their normality was verified by the Shapiro-Wilk test. We used Student's t-test and Mann-Whitney's test to compare both groups. Fisher's test compared the proportions between sexes and the different stages of sexual maturation between groups. To analyze the FATMAX values according to anthropometric and cardiorespiratory fitness variables, we used Pearson's correlation and multiple linear regression. We used the software SPSS to analyze the data and considered $p$ values $\leq 0.05$ as significant.

\section{RESULTS}

Table 1 shows the general characteristics of the study participants. The distribution of the characteristics was similar in both groups regarding sex and sexual maturation stage. There was also no significant difference between groups in terms of age, body mass, height, BMI, BMI z-scores, $\mathrm{VO}_{2} \max (\mathrm{L} / \mathrm{min})$, and $\mathrm{R}$ at the FATMAX point $\left(\mathrm{R}_{\text {FATMAX }}\right)$ between the groups. The group with T1DM showed a mean concentration of $\mathrm{HbA} 1 \mathrm{c}$ of $9.39 \pm 1.25 \%$. Both FATMAX values $(\mathrm{p}<0.01)$ and $\% \mathrm{VO}_{2}$ at the

Table 1. General characteristics of the groups.

\begin{tabular}{|c|c|c|c|}
\hline & DG $(n=10)$ & $C G(n=12)$ & $\mathrm{P}$ \\
\hline $\mathrm{HbA1c}$ & $9.39( \pm 1.25)$ & - & - \\
\hline $\operatorname{Sex}(M / F)$ & $(5 / 4)$ & $(4 / 8)$ & 0.503 \\
\hline Tanner (4/5) & $(1 / 9)$ & $(2 / 10)$ & 0.509 \\
\hline Age (years) & $13.80( \pm 1.90)$ & $12.78( \pm 1.39)$ & 0.163 \\
\hline $\mathrm{BM}(\mathrm{kg})^{+}$ & $53.88( \pm 14.62)$ & $57.39( \pm 8.33)$ & 0.100 \\
\hline Height $(\mathrm{m})$ & $1.59( \pm 0.14)$ & $1.61( \pm 0.10)$ & 0.767 \\
\hline BMI z-score & $0.39( \pm 0.84)$ & $0.81( \pm 0.85)$ & 0.258 \\
\hline $\mathrm{VO}_{2} \max (\mathrm{L} / \mathrm{min})$ & $2.09( \pm 0.54)$ & $1.87( \pm 0.50)$ & 0.345 \\
\hline $\mathrm{R}_{\text {FATMAX }}{ }^{\dagger}$ & $0.81( \pm 0.005)$ & $0.80( \pm 0.008)$ & 0.100 \\
\hline FATMAX $^{+}$(Kcal/min) & $3.36( \pm 0.51)$ & $5.33( \pm 1.73)$ & $0.01^{*}$ \\
\hline$\% \mathrm{VOO}_{2 \text { FATMAX }}$ & $35( \pm 11)$ & $60( \pm 12)$ & $0.001^{* *}$ \\
\hline
\end{tabular}

$\mathrm{DG}=$ group with type 1 diabetes mellitus; $\mathrm{CG}=$ control group; $\mathrm{BM}=$ body mass; $\mathrm{BMI} z$-score = body mass index $\mathrm{z}$-score; $\mathrm{VO}_{2}$ max = maximum oxygen consumption; $\mathrm{R}_{\mathrm{FATMAX}}=$ ventilatory exchange ratio at the Fatmax point; FATMAX = maximal fat oxidation; $\% \mathrm{VO}_{2 F A T M A X}=$ percentage of maximum oxygen consumption at the FATMAX point; ${ }^{+}$Nonparametric data; $p<0.05 ;\left(^{*}\right) ; p<0.01{ }^{* *}$.
FATMAX point (\%VO 2FATMAX, $\left._{1}=0.001\right)$ were lower in the T1DM group compared with the control group.

Table 2 shows Pearson's correlation coefficients for FATMAX values and cardiorespiratory fitness and anthropometric variables. FATMAX values correlated inversely with BMI z-scores $(r=-0.76)$ and $\mathrm{HbA} 1 \mathrm{c}$ values $(r=-0,77)$, while the $\% \mathrm{VO}_{2 \text { FATMAX }}$ correlated inversely with age $(r=-0.81)$, BMI z-scores $(r=-0.65)$, and $\mathrm{VO}_{2} \max (r=-0.81)$.

On multiple linear regression, serum $\mathrm{HbA} 1 \mathrm{c}$ values explained $54 \%$ $(p=0.009)$ and the BMI z-scores explained 3.1\% $(p=0.009)$ of the variation in FATMAX values in adolescents with T1DM, as shown in the Figures $2 \mathrm{~B}$ and $2 \mathrm{C}$, respectively.

Table 2. Correlation matrix between maximal fat oxidation (FATMAX) and anthropometric and cardiorespiratory fitness variables in adolescents with type 1 diabetes mellitus.

\begin{tabular}{|c|c|c|c|c|c|c|c|}
\hline & Age & HbA1c & BMI z-score & $\mathrm{VO}_{2}$ max & $\mathbf{R}_{\text {FATMAX }}{ }^{\dagger}$ & FATMAX $^{+}$ & $\% \mathrm{VO}_{2 \text { FATMAX }}$ \\
\hline Age & 1.00 & 0.142 & 0.414 & $0.847^{*}$ & -0.375 & -0.030 & $-0.812^{*}$ \\
\hline $\mathrm{HbA1c}$ & & 1.00 & $0.680^{*}$ & 0.159 & -0.211 & $-0.770^{*}$ & -0.568 \\
\hline BMI z-score & & & 1.00 & 0.243 & -0.521 & $-0.769^{*}$ & $-0.658^{*}$ \\
\hline $\mathrm{VO}_{2} \max$ & & & & 1.00 & -0.096 & 0.072 & $-0.813^{*}$ \\
\hline $\mathrm{R}_{\text {FATMAX }}{ }^{+}$ & & & & & 1.00 & 0.289 & 0.280 \\
\hline FATMAX $^{+}$ & & & & & & 1.00 & 0.492 \\
\hline$\% \mathrm{VO}_{2 \text { FATMAX }}$ & & & & & & & 1.00 \\
\hline
\end{tabular}

Nonparametric data; ${ }^{*} \mathrm{p}<0.05$

\section{DISCUSSION}

Current guidelines recommend that young individuals with diabetes practice physical exercise regularly due to its psychological, social, emotional, and health benefits. ${ }^{4,15}$ This recommendation is based on the evidence that regular exercise has an important role in the treatment of diabetes. ${ }^{6,8,9}$ According to guidelines published by the International Society for Pediatric and Adolescent Diabetes, ${ }^{16}$ individuals with diabetes practicing exercise must consider all the factors that influence its response, including the intensity, duration, and type of exercise, performance level, time and content of the meal consumed before the exercise, type of insulin administered and time of the last application.

The objective of this study was to compare the FATMAX values and cardiorespiratory fitness in adolescents with and without T1DM and to verify the association of the FATMAX values with anthropometric and cardiorespiratory fitness variables in the diabetic group. The results showed that adolescents with T1DM presented $\mathrm{VO}_{2}$ max values similar to those of the participants in the control group. Studies, in general, demonstrate that adolescents with T1DM have lower $\mathrm{VO}_{2}$ max when compared with controls. ${ }^{3,17}$ However, a research has shown similar aerobic capacities in healthy adolescents and adolescents with T1DM with adequate glycemic control and absence of chronic complications. ${ }^{17}$ This fact was also observed in the present study despite the poor metabolic control of the diabetic group.

Healthy individuals and patients with T1DM who practice regular physical activity show improvement in cardiorespiratory fitness, body composition, and glycemic control., ${ }^{3,4}$ In addition to all these benefits, physical exercise can also improve glycemic control in individuals with T1DM. ${ }^{8,9,18}$ Although the practice of exercise is considered part of the treatment in patients with T1DM, the American College of Sports Medicine and American Diabetes Association emphasize the need for strategies to enable individuals with T1DM to participate safely in programs of physical activity with a reduced risk of hypoglycemia. ${ }^{19}$ Young individuals with T1DM should choose the physical activity of their preference and practice it regularly if possible, maintaining consistency in terms of exercise extent and duration and time of the day when it is practiced, so that these individuals can enjoy the physical and psychosocial benefits that physical exercise promotes. 6,15 


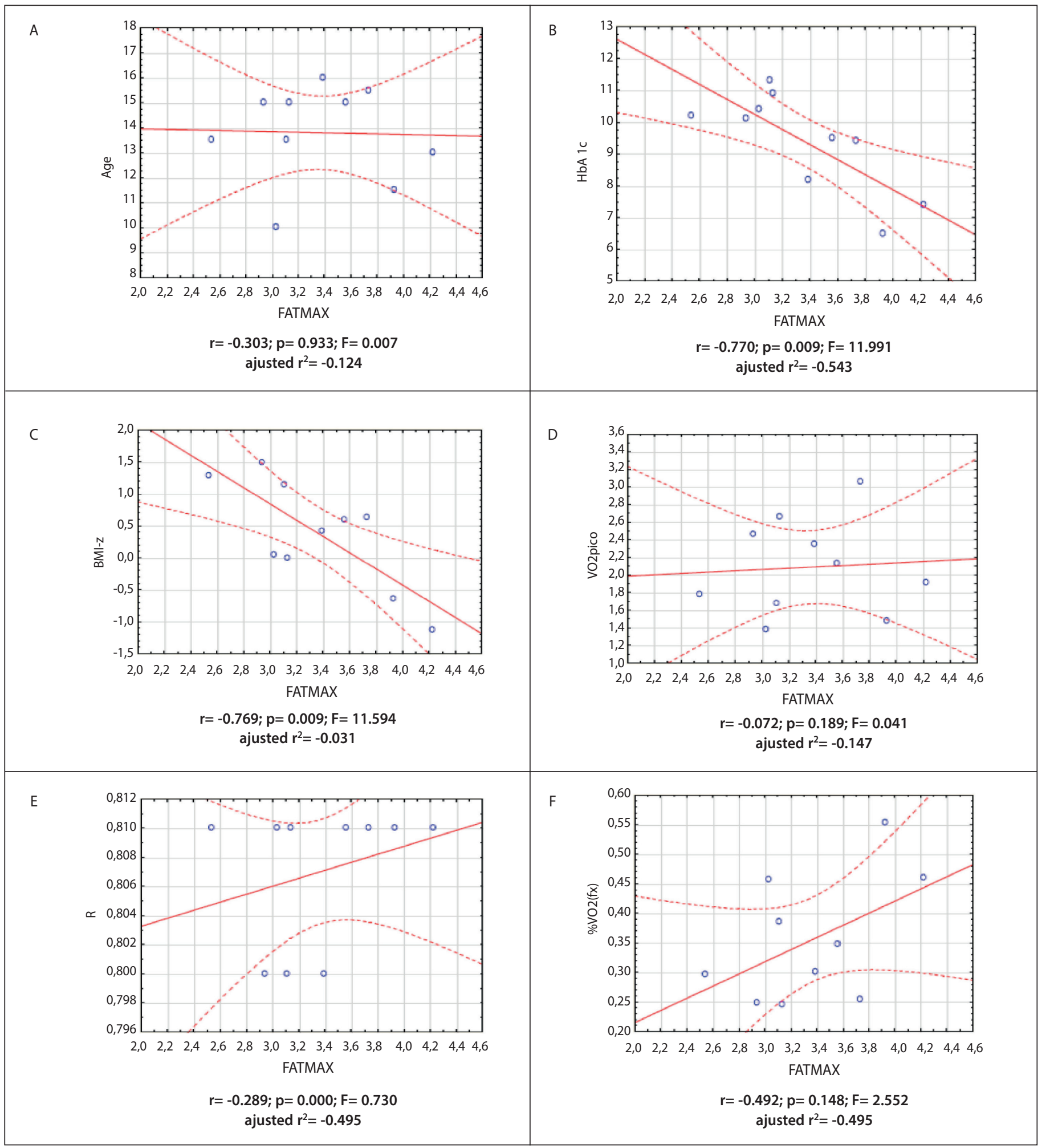

Figure 2. Dispersion diagrams showing multiple linear correlations between anthropometric, cardiorespiratory, and biochemistry variables versus FATMAX in adolescents with type 1 diabetes mellitus.

In this study, adolescents in the T1DM group had lower average

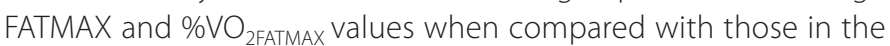
control group. (Table 1) Lower fat oxidation in patients with diabetes may be associated with an inability to decrease circulating insulin levels, inhibiting lipolysis and leading to a possible increase in the hepatic uptake of fatty acids, ${ }^{20}$ as well as an increase in GLUT4 recruitment to the cellular membrane and activation of muscle hexokinase, enabling the phosphorylation of glucose and increasing glucose muscle uptake. ${ }^{21}$

A research in adults with T1DM has shown that high insulin doses during moderate aerobic exercise were associated with a fat oxidation rate of around $15 \%$ of the $\mathrm{VO}_{2}$ max. With a decrease in insulin dose, the rate increased to $23 \% .^{18}$ These values are lower than those found in adults without diabetes, who have a fat oxidation rate of $40 \%$ in the same conditions, ${ }^{22}$ a result similar to that found in our study.

The occurrence of hyperglycemia alone inhibits the oxidation of lipids during exercise. In contrast, when individuals with T1DM perform exercise while presenting normal blood glucose levels ( $\sim 97$ $\mathrm{mg} / \mathrm{dL}$ ) and insulin levels of around $122 \mathrm{mmol} / \mathrm{L}$, they show similar lipid oxidation rates than nondiabetic individuals. ${ }^{23}$ Accordingly, decreases in blood glucose levels during exercise in individuals with 
T1DM may be attributed to increased rates of carbohydrate oxidation associated with glucose uptake by muscle cells. This last fact is induced by increased AMPK activity in response to muscle contraction and requirement of ATP generation, leading to translocation of GLUT4 to the cell membrane by signaling pathways that are different and independent from those of insulin. ${ }^{24}$

However, adipose tissue lipolysis increases the availability of fatty acids to the muscle, which according to evidence is an important determinant of fat oxidation rates during exercise., ${ }^{8,23}$ Moreover, the contribution of fat to the energy expenditure during exercise is largely regulated by the intensity of the exercise, although several other factors are also involved, including the duration of the exercise, age, sex, degree of sexual maturation, diet, training, circulating insulin levels, and availability of energetic substrates. ${ }^{24}$

Fat oxidation occurs at higher rates in children and adolescents, who may achieve $\mathrm{VO}_{2}$ max values above $75 \%{ }^{25}$. Indeed, adolescents with diabetes in our study reached the FATMAX at $35 \%$ of the $\mathrm{VO}_{2}$ max intensity, while the adolescents in the control group reached it at $60 \%$. Other analyses conducted in adolescents without diabetes, classified according to the pubertal or post-pubertal stage, showed FATMAX values between $55 \%$ and $40 \%,{ }^{24,25}$ which were very close to those in the control group in our study.

A recent study has shown that patients with T1DM have a significant decrease in ATP synthase and glucose-6-phosphatase activity. ${ }^{26}$ In addition, another study in young patients with diabetes has shown that this decreased enzymatic activity leads to mitochondrial dysfunction due to lower oxidative phosphorylation. ${ }^{27}$ These findings, associated with a reduced FATMAX observed in our study subjects with diabetes, leads us to believe that patients with T1DM may have impaired delivery of both substrates for cellular oxidation during and after exercise.

Oxidation of energetic substrates, such as carbohydrate, fat, and protein, increases during aerobic exercise in proportion to the intensity of the activity. 23,25 In our study, adolescents with diabetes had similar $\mathrm{VO}_{2}$ max values as those in the control group. There was no correlation between $\mathrm{VO}_{2}$ max values and FATMAX results, but an indirect correlation was observed between $\mathrm{VO}_{2}$ max with $\% \mathrm{VO}_{2 \text { FATMAX }}$ Therefore, maximization of fat oxidation during exercise seems to bring health benefits since changes in fat metabolism may help control weight and reduce the dependence of glucose as the main source of energy in patients with diabetes, minimizing hypoglycemia during exercise9,16,28.
Another important finding of our study was the inverse correlation between $\mathrm{HbA} 1 \mathrm{c}$ and FATMAX during exercise $(r=-0,77$ and $p<0.05)$. This suggests that patients with better glycemic control tend to have increased fat oxidation rates during exercise. However, due to our small sample size, we were unable to separate patients with good glycemic control from those with poor control and compare their FATMAX rates. A study in mice has shown that a dysfunction in beta oxidation is associated with the development of hepatic steatosis and, consequently, increased insulin resistance. ${ }^{29}$ In the long term, dysfunction in beta oxidation favors lipid accumulation, increases cardiovascular risk, and induces lipotoxicity. ${ }^{20,23}$ Still, new studies clarifying the importance of fat oxidation and its role in glycemic control are necessary.

Some limitations of our study should be mentioned. First, since this was a cross-sectional study, we were unable to establish a cause-and-effect association between FATMAX, cardiorespiratory fitness, and T1DM. Second, the small number of participants included in our study prevents a generalization of the results to children and adolescents with T1DM. However the Lusk's table used to estimate the FATMAX values shows good agreement and is a noninvasive technique such as arterial cannulation and muscle biopsies ${ }^{24}$, which can be easily implemented in practice by health professionals.

\section{CONCLUSION}

Physical exercise has a strong influence in decreasing cardiovascular risk factors, lipid disorders, insulin resistance, and glucose intolerance. It is also an important tool in diabetes treatment since it enhances fat oxidation and improves the quality of life in individuals with diabetes. However, our results showed that adolescents with T1DM presented lower FATMAX values during a maximal aerobic test when compared with adolescents without diabetes. These results may contribute to emphasize the prescription of exercise to patients with diabetes, and help choose the appropriate exercise intensity to prevent hypoglycemia.

\section{ACKNOWLEDGMENTS}

We would like to thank CNPq (project 487557/2-13-1) and CAPES for the financial support to conduct this research. The third author was supported by grants CAPES and last author is researcher of CNPq.

All authors declare no potential conflict of interest related to this article

AUTHORS' CONTRIBUTIONS: Each author made significant individual contributions to this manuscript. ICJ (0000-0002-1072-9028)* and LPGM (0000-0002-7762-2727)*: were major contributors in the writing of the manuscript; VAL (0000-0002-9413-4645)*,JPD (0000-0002-4132-8809)* and SNF (0000-0002-3987-3998)*: participated in the collection of clinical data and tests performed with patients; NL (0000-0002-4752-6697)*: directed and coordinated the entire research project, in addition to revising the manuscript. All authors participated actively in the discussion of results and review, and approved the final version of the manuscript. *ORCID (Open Researcher and Contributor ID).

\section{REFERENCES}

1. Aguiree F, Brown A, Cho NH, Dahlquist G, Dodd S, Dunning T, et al. IDF Diabetes Atlas. 6th ed. Brussels, Belgium: International Diabetes Federation, 2013.

2. Negrato CA, Dias JP, Teixeira MF, Dias A, Salgado MH, Lauris JR, et al. Temporal trends in incidence of type 1 diabetes between 1986 and 2006 in Brazil. J Endocrinol Invest. 2010;33(6):373-37.

3. Lima VA, Mascarenhas LP, Decimo JP, Souza WC, França SN, Leite N. Efeito agudo dos exercícios intermitentes sobre a glicemia de adolescentes com diabetes tipo 1. Rev Bras Med Esporte. 2017;23(1):12-15.

4. Diabetes Prevention Program Research Group. Long-term effects of lifestyle intervention or metformin on diabetes development and microvascular complications over 15-year follow-up: the Diabetes Prevention Program Outcomes Study. Lancet Diabetes Endocrinol. 2015;3(11):866-75.

5. Dahlberg ER, Spets E, Svedbo Engström M, Larshans M, Leksell J. Experiences of hypoglycaemia in adults with diabetes mellitus. J Diabetes Treat. 2017;3(J111):1-8.

6. Zinman B, Ruderman N, Campaigne BN, Devlin JT, Schneider SH; American Diabetes Association. Physical activity/exercise and diabetes mellitus. Diabetes Care. 2003;26(Suppl 1):S73-7.
7. Yardley JE, Sigal RJ. Exercise strategies for hypoglycemia prevention in individuals with type diabetes. Diabetes Spectr. 2015;28(1):32-8.

8. Mascarenhas LP, Decimo JP, Lima VA, Kraemer GC, Lacerda KR, Nesi-França S. Physical exercise in type 1 diabetes: recommendations and care. Motriz Rev Educ Fís. 2016;22(4):223-30.

9. Leclair E, de Kerdanet M, Riddell M, Heyman E. Type 1 Diabetes and Physical Activity in Children and Adolescents. J Diabetes Metab. 2013;510:1-10.

10. Tanner JM. Normal growth and techniques of growth assessment. Clin Endocrinol Metab. 1986;15(3):411-51.

11. WHO. Growth reference data for 5-19 years. 2006 [access in 2017 feb 10]. Geneva: World Health Organization. Available in: www.who.int/growthref/who2007_bmi_for_age/en/index.html

12. Rowland TW. Exercise and children's health. Champaign: Human Kinetics Publishers, 1990

13. Tanaka H, Monahan KD, Seals DR. Age - predicted maximal heart rate revisited. J Am Coll Cardiol. 2001;37(1):153-6. 
14. Lusk, G. Animal calorimetry: twenty-fourth paper. Analysis of the oxidation of mixtures of carbohydrate and fat. J. Biol Chem. 1924;59:41-2.

15. de Lima VA, Mascarenhas LP, Decimo JP, de Souza WC, Monteiro AL, Lahart I, et al. Physical Activity levels of adolescents with type 1 diabetes physical activity in T1D. Pediatr Exerc Sci. 2017;29(2):213-9.

16. Sperling MA. ISPAD Clinical Practice Consensus Guidelines 2014. Assessment and monitoring of glycemic control in children and adolescents with diabetes. Pediatr diabetes. 2014;15(Suppl 20):102-14.

17. Komatsu WR, Gabbay MA, Castro ML, Saraiva GL, Chacra AR, de Barros Neto TL, et al. Aerobic exercise capacity in normal adolescents and those with type 1 diabetes mellitus. Pediatric Diabetes. 2005;6(3):145-9.

18. Riddell MC, Sigal RJ. Physical activity, exercise and diabetes. Can J Diabetes. 2013;37(6):359-60.

19. Colberg SR, Sigal RJ, Fernhall B, Regensteiner JG, Blissmer BJ; Rubin RR, et al. Exercise and type 2 diabetes the American College of Sports Medicine and the American Diabetes Association: joint position statement Diabetes Care. 2010;33(12):e147-67.

20. Silveira LR, Pinheiro $\mathrm{CH}$, Zoppi CC, Hirabara SM, Vitzel KF, Bassit RA, et al. Regulation of glucose and fatty acid metabolism in skeletal muscle during contraction. Arq BrasEndocrinol Metabol. 2011;55(5):303-13.

21. Chokkalingam K, Tsintzask K, Norton L, Jewell K, Macdonald IA, Mansell PI. Exercise under hyperinsulinemic conditions increases whole-body glucose disposal without affecting muscle glycogen utilization in Type 1 diabetes. Diabetologia. 2007;50(2):414-21.

22. Jenni S, Oetliker C, Allemann S, Ith M, Tappy L, Wuerth S, et al. Fuel metabolism during exercise in euglycaemia and hyperglycaemia in patients with type 1 diabetes mellitus - a prospective single-blinded randomised crossover trial. Diabetologia. 2008;51(8):1457-65.
23. Jeukendrup AE, Achten J. Fatmax: a new concept to optimize fat oxidation during exercise? Eur J Sport Scie. 2001;1:(5)1-5.

24. Venables MC, Achten J, Jeukendrup AE. Determinants of fat oxidation during exercise in healthy men and women: a cross-sectional study. J Appl Physiol (1985). 2005;98(1):160-7.

25. Riddell MC, Jamnik VK, Iscoe KE, Timmons BW, Gledhill N. Fat oxidation rate and the exercise intensity that elicits maximal fat oxidation decreases with pubertal status in young male subjects. J Appl Physiol (1985). 2008;105(2):742-8.

26. Kacerovsky M, Brehm A, Chmelik M, Schmid AL, Szendroedi J, Kacerovsky-Bielesz G, et al. Impared insulin stimulation of muscular ATP production in patients with type 1 diabetes. J Intern Med. 2011;269(2):189-99.

27. Cree-Green M, Newcomer BR, Brown MS, Baumgartner AD, Bergman B, Drew B, et al. Delayed skeletal muscle mitochondrial ADP recovery in youth with type 1 diabetes relates to muscle insulin resistance. Diabetes. 2015;64(2):383-92.

28. Miculis CP, de Campos W, Gasparotto GS, Silva MP, Mascarenhas LP, Boguszewski MC. Correlation of cardiorespiratory fitness with risk factors for cardiovascular disease in children with type 1 diabetes mellitus. J Diabetes Complications. 2012;26(5):419-23.

29. Ibdah JA, Perlegas P, Zhao Y, Angdisen J, Borgerink H, Shadoan MK, et al. Mice heterozygous for a defect in mitochondrial trifunctional protein develop hepatic steatosis and insulin resistance. Gastroenterology. 2005;128(5):1381-90. 